Literature Reviews

\title{
Soya Beans Production in Zambia: Opportunities and Challenges
}

\author{
Brivery Siamabele \\ Pan African University, Institute of Governance, Humanities and Social Sciences, Yaounde Cameroon
}

Article history

Received: 05-02-2019

Revised: $10-05-2019$

Accepted: 13-05-2019

Email: briverys@gmail.com

\begin{abstract}
The soya bean production opens doors of opportunities for Zambian farmers. Notably, the climate in Zambia is largely favourable for soya production and the arable land is vast enough to accommodate future expansion. Most importantly, soya is a very profitable crop. On the other hand, there are some challenges which affect soya production such as poor soils aggravated by low fertilizer use, poorly developed agricultural advisory services and farmers' inability to access favourable input and outputs markets. Moreover, farmers predominantly find improved soya seeds expensive. It is therefore expedient for policymakers and the government to join hands to strengthen the linkage between small-scale farmers, commercial producers and the market to assist them to commercialize their products in full scale. In order to address these challenges, the authors suggest that the Zambian government should put farming inputs (such as inoculum seeds), post-harvest management lessons and some necessities at the disposal of farmers. Moreover, the government has to be serious about improving country's infrastructure especially rural roads to enhance soya bean trade. Lastly, the policymakers should take the responsibility of orchestrating soya trade to avoid trade distrust which results from rigged scales. If these recommendations are taken seriously soya bean production is likely to speed up economic growth and alleviate poverty in Zambia.
\end{abstract}

Keywords: Soya Beans, Livelihoods, Poverty, Food Security

\section{Introduction}

In the early stages of development, the growth of the agricultural sector is important for achieving development objectives (Diao et al., 2010). Therefore, for a developing country like Zambia, growth in the agricultural sector is the clearest avenue through which sustainable economic growth and poverty reduction can be achieved. It is widely accepted that broad-based growth in agriculture incomes is essential to stimulate economic growth in primarily agrarian societies (Diao and Hazell et al., 2010).

Consequently, Zambia's agriculture sector has been identified as key to unlocking economic growth and it provides the main support for Zambia's rural economy. In other words, when growth comes from sectors that most poor people work in, there is a much higher likelihood to address poverty. Zambia is moving towards economic diversification and this includes the introduction of cash crops that can improve the livelihoods of the small scale farmers in rural areas. Soya beans are one of the cash crops being promoted by the government of Zambia among small scale farmers. Most of the Zambian small scale farmers on the Eastern province and Luapula, to mention but a few, have been involved in the soya beans production and this leads to the aim of this paper. It is, therefore, necessary to look at the soya beans production in Zambia. Focusing on the opportunities that are pulling the farmers into the crop production and establish challenges faced by the small scale farmers in growing soya beans in Zambia.

\section{Background of Soya Beans Production in Zambia}

Globally, soya beans area has expanded rapidly over the last decades, from 26.5 million hectares in 1966 to 
61.1 million hectares in 1996 and 121.5 million hectares in 2016 (FAO, 2017). Most of this expansion in area has come from the USA, Brazil and Argentina in response to the growing demand for feed from the livestock industry.

Soya beans can be referred to as one of the miracle crops which provide oil and vegetable protein more than many other plants and are classified as legumes or another type of beans. They are classified under the oilseed category of edible oil which is produced in large quantities. This crop is versatile because it embraces diverse climatic conditions and different types of soil, something not done by many crops. According to Ecogreeen.www.ecogreen (2014), soya beans are one of the widely produced oilseed products not only in Africa but in the whole world. With advances in scientific research, within a period of two decades, after the production of soya beans in economic scales, different byproducts are being extracted from soya beans and some of them are useful for human consumption while others are beneficial for the production of animal feed and industrial application (Ecogreeen.www.ecogreen, 2014).

The production of soya beans dates as back as 50 centuries ago and was first discovered in China before being exported to other continents like America in the 1800s (Ecogreeen.www.ecogreen, 2014). Soya beans are used for various purposes. In America, for instance, soya beans were used to brew coffee, especially during the civil war when real coffee was scarce and they were also produced by farmers as forage for livestock especially cattle (Ecogreeen.www.ecogreen, 2014).

The situation is different, however, in Asia (China, India, Indonesia, Japan, People's Democratic Republic of Korea, Thailand, Vietnam) and in Africa (Uganda, Nigeria, Zambia, South Africa), where soya beans tend to be produced-sometimes predominantly - on a smaller scale, involving labour-intensive cultivation methods. In these regions, the contribution of soya beans to the food security of small rural households tend to be relatively more significant, nonetheless, its overall importance remains low due to the crop's limited role (FAO, 2003).

Broadly, Sub-Saharan Africa (SSA) is one of the regions where the human population increases faster than food production yet the majority depends on agriculture and live in rural areas (Van Ittersum et al., 2016). Food insecurity is a major concern in SSA. Protein deficiency exacts a greater toll from infants, children, pregnant and lactating women in SSA than anywhere else in the world, partially because starchy foods are widely consumed and animal protein is often too expensive and out of reach for low-income families. Increases in protein production are needed in SSA countries to address the challenges of food security by increasing income and improving human nutrition at the household level. To fill this gap between the demand and supply of food, especially protein, growing soya beans as a tropical crop in SSA is an ideal solution (Kolapo, 2011; Masuda and Goldsmith, 2009; Hartman et al., 2011; Sinclair et al., 2014).

From the 1970 s to 2000 s SSA has realized an exponential growth of soya beans which range from 13,000 tons to 2,300 000 tons (Khojely et al., 2018; Woomer et al., 2012). The increase has been the primary factor in raising soya beans production in SSA by 177fold, from $13,000 \mathrm{t}$ in the early 1970 s to $2,300,000$ tons in 2016 (OGAFAS, 2017). In terms of the ranking in soya beans production as of the year 2016, South Africa is the largest followed by Nigeria, Zambia and Uganda in SSA (OGAFAS, 2017).

Since the founding of Zambia, the promise of economic opportunities has been a central component of Zambia's development vision. The Zambian economy has grown at an average of $7 \%$ over the past decade, one of the fastest in Sub-Saharan Africa. However, the benefits of growth have been unevenly distributed; a reflection of regional differences in factor endowments and most importantly of the economy's over-reliance on a single commodity to a single market.

Zambia is a significant player in soya beans production and processing with demand largely driven by a fast-growing poultry sector. Zambia produced 112,000 tons of soya beans in 2010 and processed 90,000 tons in the same year (TBSP, 2010). Zambia is largely self-sufficient in soya beans production. According to TBSP (2010), 85\% of the supply of soya beans comes from commercial farmers, characterized by high use of inputs, use of irrigation and relatively high yields of over 2.9 tons per hectare and only $2 \%$ of soya beans supply in 2010 came from imports. The processing sector has an installed crushing capacity of approximately 125,000 tons, which is currently more than sufficient for domestic demand, making Zambia a net exporter regionally (TBSP, 2010).

Research has indicated that soya beans are cultivated in nearly all the parts of Zambia, but mainly in the Eastern, Central and Northern Provinces. According to Lubungu et al. (2013:13) from 2001 to 2010 the Eastern province was responsible for $42 \%$ of the soya beans produced in Zambia.

According to Ekanayake and Iskandarani (2013:6-7) the crop forecasting survey of the 2012/2013 revealed that the production of soya beans increased by $29 \%$ during the 2011/2012 period while the area on which soya was planted had increased by $45 \%$. Equally important, just as Lubungu et al., (2013) rightly pointed out, the study conducted by Ekanayake and Iskandarani (2013) established that the Eastern Province produced $38 \%$ of the national soya beans in $2012 / 2013$ with only a $4 \%$ decline from the $2001-2010$ production. 
Worrisome is the fact that research revealed that for the $2014 / 2015$ period the national yield dropped by $5 \%$ despite the $11.2 \%$ increase in the area on which soya beans are planted (NAIS, 2015; MAL, 2016). Possible factors attributed to this decline were sporadic rainfall, low soil fertility and poor management practices. Compared to other crops soya beans are the most preferred crops in Zambia. Nevertheless, farmers often sell just $70 \%$ of the harvested soya beans and prefer to keep $30 \%$ as seed for the next planting season (Lubungu et al., 2013)

Soya beans have lots of benefits not only for oil, meal and soil nutrition. Soya beans animal feed accounted for $89 \%$ of soya beans consumption in 2010 , with the majority of this used for the poultry sector, which has recently grown by $20 \%$ per year (Munguzwe et al., 2014). Human consumption, in form of soy chunks and soy products like 'Yummy Soy', account for the remaining $11 \%$ and is also one of the fast- growing sectors, expected to grow by $8 \%$ per year over the medium term to 2020 (Munguzwe et al., 2014).

In support of the above production performances, the government of Zambia has firmly committed itself to the diversification of Zambia's economy through increased participation of other sectors in growth generation. Such commitment has improved the focus and concentration on soya beans among many other cash crops. The government is promoting diversification to cash crops including; cotton, cashew nuts, soya beans, cassava and rice. This move has been taken because the government is aware that at least $48 \%$ of the Zambians rely on agriculture, especially to produce feedstuff for their livestock and for employment and also because the studies showed that the soya beans production contributed $4.8 \%$ of the Gross Domestic Product (GDP) in 2017 (ZASR, 2017). Ultimately, Zambia has 58\% of arable land and only $14 \%$ is under cultivation and $11 \%$ of Zambian population is small to medium scale farmers producing $100 \%$ of the traditional maize crop for food security (MAL, 2016. In the 2016/17 season, Zambia was expected to produce 351,416 MT of soya beans, an increase of $31 \%$ from 267,490 MT from the previous season (MAL, 2016). Of this output, smallholder farmers were estimated to account for $42 \%$ of the production compared to $32 \%$ in the previous season (ZASR, 2017).

\section{Opportunities Realized from Growing Soya Beans in Zambia}

Over the last 20-30 years, consistent improvements in average yield levels and reductions in production costs have steadily improved the competitive position of soya beans among arable crops (Thoenes, 2012). Among oil crops, soya covers a leading role at the global scale: Today, soya beans account for about $35 \%$ of the total harvested area devoted to annual and perennial oil crops (Thoenes, 2012) the crop's share in global oilseed output is estimated at over $50 \%$ (Thoenes, 2012).

Zambia is largely self-sufficient in soya bean production. According to TBSP (2010), 85\% of the supply of soya comes from commercial farmers, characterized by high use of inputs, use of irrigation and relatively high yields of over 2.9 tons per hectare. He further pointed out that only $2 \%$ of soya beans supply in 2010 came from imports (TBSP, 2010). The processing sector has an installed crushing capacity of approximately 125,000 tons, which is currently more than sufficient for domestic demand, making Zambia a net exporter regionally (TBSP, 2010).

One of the benefits of soya beans production in Zambia emerges from the face of the high level of growth; the soya beans sector appears to be positioned for growth in Zambia. Given its location, Zambia can export soya beans and processed soya beans products to regional markets like Zimbabwe and South Africa, especially given the exclusive use of non $\square$ GMO strains. The majority of land with agricultural potential in Zambia is still uncultivated and is well suited to soya beans production; and the construction of a new processing facility in the Lushanya region of 30,000 tons, which was expected to be operational by the end of 2011, appeared to validate the opportunity (TBSP, 2010). Looking at Zambia's regional contribution, soya beans give the manifests the existence of a vibrant market.

Broadly, soya beans are one of the most valuable crops in the world, due to its multiple uses as a source of livestock and aquaculture feed, protein and oil (Pawar et al., 2011) for the human diet and biofuel (Glycine max, 2012). It is one of the tropical legume crops that have shown sustained growth in all the production parameters (cultivated area, yield and production) over the last 4 decades (FAOSTAT, 2010).

Soya beans have approximately $40 \%$ content of protein which means that it is fruitful for better nutrition for the rural populace (Dixit et al., 2011). Unlike regular beans, groundnuts and cowpeas people prefer to mix soya with other ingredients to make a nutritious rich protein blend which can be used to make porridge. Given high levels of under-nutrition in Eastern Province (USAID, 2011), it is believed that soya porridge can improve the health of the malnourished children.

In addition, soya production also has the potential agronomic benefit of rejuvenating soils. Soya bean canopies protect the soil from recurrent erosion, fix atmospheric nitrogen into the soil and decaying root residues improve soil fertility. Soil improvement leads to higher levels of sustainable agriculture with minimal input requirement. In addition, soya bean has the capacity to fix nitrogen even with native Bradyrhizobium strains and fits well into current crop rotations because of its climatic 
resilience (Mapfumo and Mtambanengwe, 2005). The market of soya beans products for human consumption such as soy milk, chunks, burgers, sausages, hot dogs, mince and polonies to mention but a few (Mapfumo and Mtambanengwe, 2005).

Furthermore, soya beans are high value and profitable crop. The commercial utilization of soya beans and its products such as oil and meal determine the economic viability of the soya beans production. The aforementioned products- oil and meal make up 2/3 of soya beans' economic value.

Soya oil and meal are consumed worldwide as food and animal feedstuff respectively. In Zambia, the soya beans are mostly used as industrial product. The byproduct (cake) is fed directly to animals or processed with other ingredients into animal feed-stock. As animalfeed, soya by-products provide relatively low cost, highquality protein to feed rations. With a livestock revolution underway in developing countries, including Zambia, industrial demand for soya is likely to increase. The growing demand for soya offers significant opportunity for smallholder farmers to improve their cash base (Delgado, 1999).

Lastly but not the least, soya bean at household level impacts farmer's income and income distribution, intrahousehold gender relations, allocation and control of resources, material welfare, human capital development, household food security (Glycine max, 2012). At the community level, it is hypothesized that the adoption of soya beans has had an effect on attitudes and values, labour, market development, social equity, innovativeness and the potential sustainability of soya beans production (Delgado, 1999). Broadly, these opportunities have motivated most governments to support soya beans as it helps largely in the poverty reduction in rural areas. It is a crop that attacks poverty on its neck.

\section{Challenges Faced in Growing Soya Beans}

However, these opportunities are also associated with potential trade-offs across complex and interlinked agriculture and food systems, including those associated with competing land-uses, rural livelihoods and nutrition. Several challenges hold back the development of the sector and mainly this cash crop among small scale farmers and these provide points of entry for policy interventions.

Challenges faced in soya beans by small scale farmers' cuts across from inputs accessibility, rainfall dependence, production to market. Some of the challenges faced by most small scale farmers at productivity level include climate change, a decline in soil fertility over time and low availability of improved seeds and low usage of microbial inoculum (Mpepereki et al., 2000).

Other factors limiting soya bean productivity include limited availability of inputs and expertise. Farmers predominantly use recycled local soya varieties the use of yield improving production technologies (e.g., inoculum) is rather limited and expensive and this constrains their productivity. In addition, poor agronomic practices, particularly among smallholders, mean that yields are $25 \%$ lower than they could be, reducing total production and farmer profitability.

Small scale farmers are also faced with the challenge of poor road networks in rural areas. Farmers are disadvantaged when it comes to transportation of their crop to the market and implements to their farms. On the similar note, the other challenge is the farmer's perceptions that the market for soya is less certain compared to other crops, such as maize and therefore they are reluctant to rotate their cropping (not realizing that this may lead to decreased yields in the long-run) (Lubungu et al., 2013).

Soya beans processing can be a challenging business commercially, with difficult economics due to the seasonal variability of input costs and prices for oil and cake. As a result there are very few standalone processors and most are vertically integrated into animal feed manufacturing or further into livestock production. Additionally, soya beans processing requires sales of both cake and oil to be economically viable and currently, indigenous demand is heavily skewed toward oil. As a result, markets for cake need to be found in order to fully capture opportunities. Policy makers have a role to play in stimulating general demand, especially for human consumption of soya beans. They can also support producers and processors of soya beans with access to inputs and finance.

Furthermore, there exist a challenge of poor crop management practices, such as late planting and poor disease management (Lubungu et al., 2013). The extent to which harvests may be limited by these constraints is suggested by the fact that close to $40 \%$ of smallholder farmer do not harvest the entire area planted due to late planting because yields on those fields are too low to justify the cost of harvesting (IAPRI/CSO/MAL, 2012).

The soya beans sector faces challenges in delivering viable financial returns. Best in class soya beans cultivation by commercial farmers appears to be only marginally attractive, with farm gate prices of \$350 MT, almost the same as the breakeven price of $\$ 349$. And smallholder farmers are unable to achieve attractive returns, perceiving soya beans to be a more risky crop than maize, which is given a guaranteed price by the Government's Food Reserve Agency (FRA) (TBSP, 2010; Munguzwe et al., 2014).

\section{Conclusion}

Soya beans is good and friendly cash crop that is able to enhance the livelihoods of the rural farmers as it is able to improve their social, economic, cultural and 
political power in their societies. Soya beans has the opportunity in the processing of the present and growing demand of human and livestock feed, especially the growing poultry industry which is heavily dependent on soya beans as a key ingredient in the poultry feed formulations. Soya beans are attractive as a crop from a number of economic, social and environmental considerations. Soya beans provide smallholder farmers in Zambia an opportunity to diversify their household income and enhance food and nutrition security. Soya beans complement the predominately carbohydrate rich diets and diversify household income for many poor farmers. There exist a lot of challenges that small scale producers of soya beans are faced with including; technology, the high cost of equipment, is a major barrier to entry into commercial processing especially for producing products for human consumption other than cooking oil. At level of marketing, farmers distrust the buyers and complain that their scales are often rigged (Lubungu et al., 2013).

\section{Recommendations}

From the government policy makers' perspective, development of the soya beans processing sector should be understood primarily as a means for, (1) reducing expensive imports and (2) as a strategy for increasing dietary protein of citizens (either by being consumed directly or as poultry). Soya beans processing is not a significant source of value addition or spillovers to the broader economy.

There is a need to develop a robust soya beans processing agenda that addresses the above challenges especially those to do with market accessibility by the small scale farmers. Policymakers need to undertake a detailed understanding of local production and consumption potential for the full range of key soya beans and soya beans related products and develop an approach that can foster the development of an infant industry that may, despite indications of emerging price competitiveness of African production, face some price competition in its development phase before reaching minimum efficient scale.

A decision also needs to be made regarding the extent to which government through the ministry of agriculture intends to work with major multinational oilseed traders and processors, versus developing local processing capability. While in many sectors the development of local capabilities has significant broader benefits in terms of employment, skills development and income generation, the relatively low value added from soya beans processing, combined with significant positive spillovers, suggests a detailed analysis of countryspecific impacts is required in order to determine the appropriate policy balance at the country level.

There is also a need for small scale farmers to formulate corporative groups as soya beans farmers that will easy the access to inputs and further ease the challenge of transportation.

Furthermore, the government should allow and encourage many agro-dealers in soya beans across the regions that are practising the crop. There are so many benefits that can be realized from soya beans by the small scale farmers and the need for easily accessed pesticides by the farmers. This, therefore, calls for the involvement of many private hands in the expansion of soya beans.

It can finally be recommended that the government must improve the wider range of communication and learning activities on soya beans organized for rural people by educators from different disciplines, including agriculture, agricultural marketing, health and business studies. This will address the challenges of late planting, uncertainties on the market and the broader understanding of the crop.

\section{Acknowledgment}

This paper could not have been completed without the valued contributions from various people. It is my Obligation therefore, to extend my gratitude to all who helped. I wish to acknowledge my colleagues; Munalula Mulonda and Moeketsi Kali for their invaluable guidance, insights and advice as well as their positive attitude.

\section{Author's Contributions}

This paper was written by Brivery Siamabele as the author. Mr. Moeketsi Kali ( $\mathrm{PhD}$ candidate) edited the paper and took care of all the plagiarism checks. His contribution is well acknowledged in this work.

\section{Ethics}

Ethics were observed in this paper by acknowledging all the sources used in the paper. And all the references were put in the reference page.

\section{References}

Diao, X., P. Hazell and J. Thurlow, 2010. The role of agriculture in African development. International Food Policy Research Institute, Washington DC, USA.

Delgado, C.R., 1999. Livestock to 2020, the next food revolution. Food, Agriculture and the Environment. IFPRI Discussion Paper No. 28. International Food Policy Research Institute, Food and Agriculture Organization of the United Nations and the International Livestock Research Institute, Washington, D.C.

Ecogreeen.www.ecogreen, 2014. Globally Integrated Agriculture Business Group. Ecogreen.www.ecogreen. www.tropicalsoya beans.com/.../The\%20Soya 
Dixit, A.K., J.I.X. Antony, N.K. Sharma and R.K. Tiwari, 2011. Soya beans Constituents and their Functional Benefits. In: Opportunity, Challenge and Scope of Natural Products in Medicinal Chemistry, Tiwari, V. and B. Mishra (Eds.), Research Signpost, Kerala, India.

Ekanayake and Iskandarian, 2013. Innovative Smallholder Value Chain Market Improvement in Zambia.

FAO, 2003. The state of food insecurity in the world 2003. Rome.

FAO, 2007. Promoting integrated and diversified horticulture production in Maputo green zones towards a stable food security system. Roma.

FAOSTAT, 2010. Agriculture data, agricultural production. http://faostat.fao.org/site/567/

Glycine max, 2012. Multilingual multiscript plant name database. aims.fao.org > Semantics >.

Hartman, G.L., E.D. West and T.K. Herman, 2011. Crops that feed the world 2. Soybean-worldwide production, use and constraints caused by pathogens and pests. Food Security, 3: 5-17.

DOI: $10.1007 / \mathrm{s} 12571-010-0108-\mathrm{x}$

Munguzwe, H., C. Chilese, C. Bernadette and M. Mukwiti, 2014. Soybean value and market analysis. International Labour Organisation.

IAPRI/CSO/MAL, 2012. Rural agricultural livelihood surveys of 2012. IAPRI and Government of Zambia, Lusaka. catalog.ihsn.org > Home > Central Data Catalog >

Khojely, D.M., S.E. Ibrahim, E. Sapey and T. Han, 2018. History, current status and prospects of soybean production and research in sub-Saharan Africa. Crop J., 6: 226-235. DOI: 10.1016/j.cj.2018.03.006

Kolapo, A.L., 2011. Soyabeans: Africa's Potential Cinderella Food Crop. In: Soyabeans: Biochemistry, Chemistry and Physiology, Tzi-Bun, N.G. (Ed.), in Tech, Rijeka, Croatia, pp: 137-150.

Lubungu, M., W. Burke and N.J. Sitko, 2013. Analysis of the Soya Bean value chain in Zambia's eastern province. Working Paper No. 74, Indaba Agricultural Policy Research Institute (IAPRI), Zambia.

Mapfumo, P. and F. Mtambanengwe, 2005. Tapping indigenous herbaceous legumes for soil fertility management by resource-poor farmer in Zimbabwe. Agric. Ecosyst. Environ., 109: 221-233.

DOI: $10.1016 /$ j.agee.2005.03.015
Masuda, T. and P. Goldsmith, 2009. World soya beans production: Area harvested, yield and long-term projections. Int. Food Agribis. Manage. Rev., 12: 145-164.

MAL, 2016. The crop forecasting survey report for the 2015/2016 agriculture season. Republic of Zambia.

Mpepereki, S., F. Javaheri, P. Davis and K.E. Giller, 2000. Soyabeans and sustainable agriculture: Promiscuous soyabeans in southern Africa. Field Crops Res., 65: 137-149.

DOI: $10.1016 / \mathrm{S} 0378-4290(99) 00083-0$

NAIS, 2015. The crop forecasting survey for the 2014/2015 agricultural season and the food balance status for the 2015/2016 marketing season. Agriculture Minister's Speech, Republic of Zambia.

OGAFAS, 2017. United Sates Department of Agriculture, World Markets and Trade, Oilseeds, USDA, Washington, D.C., USA.

Pawar, R.S., V.M. Wagh, D.B. Panaskar, V.A. Adaskar and P.R. Pawar, 2011. A case study of soya beans crop production, installed capacity and utilized capacity of oil plants in Nanded District, Maharashtra, India.

USAID, 2011. Zambia FY 2011-2015 Multi-Year Strategy. Washington, D.C., USA.

Sinclair, T.R., H. Marrou, A. Soltani, V. Vadez and K.C. Chandolu, 2014. Soybean production potential in Africa. Global Food Security, 3: 31-40.

TBSP, 2010. Southern Africa soy, road Map-Zambia value Chain analysis. Technoserve Business Solutions To Poverty.

Thoenes, P., 2012. Trade and markets division, food and agriculture organization of the United Nations. Statistical Assistance was Provided by Marco Milo.

Van Ittersum, M.K., L.G.J. van Bussel, J. Wolf, P. Grassini and J. van Wart et al., 2016. Can subSaharan Africa feed itself? Proc. Natl. Acad. Sci. USA, 113: 14964-14969.

DOI: $10.1073 /$ pnas.1610359113.

Woomer. P.L., Baijukya, A. and Turner 201. Progress Towards Achieving the Vision of Success of Africa.

ZASR, 2017. Zambia Agriculture Status Report. https://www.researchgate.net/publication/32267643 7 Zambia 